\title{
Badanie wpływu mimicznego sprzężenia zwrotnego na percepcję zmęczenia $^{1}$
}

\author{
Katarzyna Jakubowska, Anna Piątkiewicz, Bartosz Rubaszewski, \\ Elżbieta Siekierska, Klaudia Tylkowska \\ katarzyna.jakubowska91@gmail.com \\ Instytut Psychologii \\ Uniwersytet im. Adama Mickiewicza
}

\begin{abstract}
Badanie dotyczyło wpływu mimicznego sprzężenia zwrotnego na subiektywną percepcję zmęczenia. Przebadano 75 studentów (19 - 26 lat). Badani wypełniali dwukrotnie polską adaptację skali FAS, przed i po wykonaniu zadania eksperymentalnego, polegającego na przyjęciu określonej postawy ciała oraz mimiki. W badaniu utworzono 2 grupy eksperymentalne i 1 grupę kontrolną, różniące się pod względem wykonywanego zadania. Zmienną zależną stanowiło zmęczenie, a niezależną rodzaj mimiki. Założono, że u osób które przyjmą zmęczony wyraz twarzy subiektywna ocena percepcji zmęczenia wzrośnie. Hipoteza nie została potwierdzona. Jednocześnie potwierdza to odporność wyników testu FAS na chwilowe zmiany percepcji zmęczenia i adekwatność tego narzędzia.
\end{abstract}

\section{Wprowadzenie teoretyczne}

Mimika jest istotnym elementem interakcji społecznej w życiu każdego człowieka. Wpływa na to, jak postrzegamy innych oraz jak my jesteśmy postrzegani. Według definicji słownikowej mimika to „ruchy mięśni twarzy i gra oczu wyrażające przeżywane uczuciai nastroje" (Szymczak, 1979, s.178). Warto zauważyć, iż definicja ta jest jednokierunkowa całkowicie pomija wpływ mimiki na percepcję naszego samopoczucia. Kwestia ta wzbudzała szerokie zainteresowanie już w drugiej połowie XIX wieku. Wówczas badaniem omawianego zagadnienia zajął się Karol Darwin (1872; za: Davis, Senghas, Ochsner, 2009), a w latach późniejszych poruszali ją także Izard (1971; za: Davis, Senghas, Ochsner, 2009), Zuckerman, Klorman, Larrance, Spiegel (1981; za: Strack, Martin, Stepper, 1988) oraz Laird (1984; za: Davis, Senghas, Ochsner, 2009).

\footnotetext{
${ }^{1}$ Raport $\mathrm{z}$ badania został napisany na podstawie pracy zaliczeniowej pt. „Badanie wpływu mimicznego sprzężenia zwrotnego na percepcję zmęczenia" przygotowanej w ramach przedmiotu praca empiryczna $w$ Instytucie Psychologii UAM rekomendowanej przez dr Joannę Urbańską i recenzowanej przez dr Katarzynę Kaliszewską - Czeremską.
} 
Wartym omówienia wydaje się być eksperyment, którego autorami byli Fritz Strack, Leonard L. Martin oraz SabineStepper (1988). Badanie dotyczyło hipotezy mimicznego sprzężenia zwrotnego. Udało się wówczas zaobserwować, że wyraz mimiczny może wpływać na aktualnie doświadczane emocje. Eksperyment polegał na aktywacji tych mięśni twarzy, które są odpowiedzialne za uśmiech. Osobom badanym podano instrukcję maskującą aby nie rozpoznały emocji odzwierciedlanej przez mimikę, którą przybierają. Jedną z grup eksperymentalnych proszono o trzymanie ołówka w zębach w taki sposób, aby zaangażowany został mięsień jarzmowy większy odpowiedzialny za wyrażanie radości. U drugiej grupy, trzymającej ołówek jedynie przy pomocy warg - przez co mięsień jarzmowy nie był aktywny - wymuszono minę smutną. W ostatnim etapie eksperymentu osobom badanym pokazano zabawne komiksy. Grupa, u której zaangażowano mięsień jarzmowy oceniała obrazki jako zabawniejsze. Otrzymane wyniki sugerują, że sama aktywacja odpowiednich mięśni twarzy wystarczy, aby poczuć się bardziej radosnym.

Tematyką poruszoną przez Strack'a i współpracowników (1988) zajęli się także Joshua Ian Davis, Ann Senghas oraz Kevin N. Ochsner (2009) w artykule pt. How does facia feedback modulate emotional experience?

Warto zauważyć, iż w żadnym z wyżej wymienionych źródeł nie została poruszona kwestia wpływu mimicznego sprzężenia zwrotnego na percepcję zmęczenia. Interesująca wydała nam się możliwość manipulacji oceną własnego zmęczenia za pomocą odpowiedniej mimiki dlatego postanowiliśmy przeprowadzić zmodyfikowaną przez nas wersję eksperymentu Strack'a i współpracowników (1988).

Na potrzeby eksperymentu zdefiniowaliśmy zmęczenie jako zjawisko subiektywne, na które składa się szereg czynników psychicznych (takich jak: abstrahowanie, rozważanie, kalkulowanie, odczuwanie emocji) oraz fizycznych (takich jak: mała ilość snu, aktywność fizyczna). Ponadto, zgodnie z założeniami teoretycznymi, na zmęczenie wpływ ma także przyjmowany wyraz twarzy. Przyjęliśmy powyższą definicję, ponieważ w eksperymencie badano wpływ czynników fizycznych (wymuszona mimika) na subiektywną percepcję zmęczenia. Na podstawie przesłanek hipotezy mimicznego sprzężenia zwrotnego oczekiwaliśmy, że u osób, które przyjmą zmęczony wyraz twarzy subiektywna ocena percepcji zmęczenia wzrośnie. 


\section{Badanie własne}

\section{Metoda}

Do oceny poziomu zmęczenia zastosowano Skalę zmęczenia chronicznego (FAS) (Załącznik 1), która jest adaptacją Fatigue Assessment Scale Michielsen'a, Vries'a oraz Heck'a (2004) Joanny Urbańskiej (2010). Skala ta charakteryzuje się wysokimi wskaźnikami rzetelności i trafności. Rzetelność szacowana metodą alfy Cronbacha, $\alpha=0,86$ (co świadczy o wysokiej homogeniczności), we wszystkich pomiarach, we wszystkich grupach oraz bardzo wysoką stabilnością bezwzględną $\mathrm{r}=0,981(\mathrm{p}=0,01)$ (dla grupy kontrolnej).

W wersji oryginalnej skala FAS jest skalą Likerta, co oznacza, że osoba badana udziela odpowiedzi na pięciostopniowej skali. W celu uniknięcia efektu zapamiętywania udzielonych odpowiedzi w preteście skala ta została rozszerzona z 5 do 7 odpowiedzi, gdzie 1 oznacza bardzo rzadko, a 7 - bardzo często. Możliwa do uzyskania minimalna liczba punktów wynosi 10, a maksymalna 70. Im wyższy wynik otrzymany przez osobę badaną, tym wyższy poziom zmęczenia.

\section{Procedura badania}

Badanie zostało przeprowadzone na grupie 75 studentów w wieku od 19 do 26 lat $(\mathrm{M}=22,05, \mathrm{SD}=1,66)$. W badaniu wzięło udział 48 kobiet (64\%) oraz 27 mężczyzn (36\%). Uczestnikami byli studenci Uniwersytetu im. Adama Mickiewicza oraz mieszkańcy domów studenckich „Zbyszko” i „Jagienka”, które przynależą do w/w Uniwersytetu. Eksperyment przeprowadzany był w ciągu trzech dni i odbywał się w godzinach popołudniowych i wieczornych. Przed przystąpieniem do badania uczestnicy byli proszeni o wyrażenie pisemnej zgody na udział $w$ eksperymencie. Braki $w$ danych nie wystąpiły $w$ żadnym z kwestionariuszy.

W przeprowadzonym eksperymencie zmienną zależną było zmęczenie a zmienną niezależną - rodzaj mimiki jaką przybierały osoby badane. W grupie kontrolnej uczestnikom nie została podana instrukcja dotycząca określonej mimiki. W przypadku grup eksperymentalnych, uczestnicy jednej z nich przybierali zmęczony, a uczestnicy drugiej uśmiechnięty wyraz twarzy. 
Eksperyment odbywał się w pomieszczeniu wyposażonym w trzy krzesła oraz stół, na którym znajdował się długopis, informacja dotycząca celu badania i jego poszczególnych etapów wraz ze zgodą na udział w eksperymencie. Po zapoznaniu się z materiałami, osoba badana proszona była o wypełnienie kwestionariusza FAS. Uczestnicy byli badani indywidualnie. W pomieszczeniu, poza osobą badaną, znajdowało się dwóch eksperymentatorów.

Istotną kwestią w badaniu było, aby uczestnicy nie byli świadomi celu eksperymentu dlatego zastosowana została instrukcja maskująca. Osobom badanym powiedziano, że badanie dotyczy wpływu wymuszonej postawy ciała na psychosomatyczne napięcie mięśni. Aby przedstawiony cel wydał się wiarygodnym, instrukcja dla osób badanych zwierała szczegółowy opis postawy ciała, jaką należało przyjąć. W celu sprawdzenia skuteczności instrukcji maskującej, odbyło się badanie pilotażowe z udziałem 4 osób. Następnie zadano im pytanie dotyczące celu badania. Żaden z uczestników nie podał innego celu od tego, który został podany w instrukcji maskującej. Eksperymentator poinformował badanych, że celem badania było co innego niż wskazano. Nikt nie udzielił poprawnej odpowiedzi na pytanie dotyczące tego, jaki był prawdziwy cel badania. Żadnej osobie nie przyszło także na myśl, że prawdziwym celem było sprawdzenie wpływu przyjmowanej mimiki na zmianę subiektywnego poczucia zmęczenia.

Badanie właściwe składało się z trzech grup: dwóch eksperymentalnych i jednej grupy kontrolnej. W każdej grupie badawczej eksperyment rozpoczynał się od zaproszenia osoby badanej do wydzielonego pomieszczenia, w którym znajdowało się dwóch eksperymentatorów: jeden czytający instrukcję i jeden demonstrujący postawę, jaką należy przyjąć. Osoba badana zapoznawała się z ogólną informacją dotyczącą badania oraz udzielała pisemnej zgody na udział w nim. Następnie eksperymentator wręczał osobie badanej Skalę zmęczenia chronicznego (FAS) ze zmienioną uprzednio skalą odpowiedzi. Kiedy badany wypełnił skalę FAS, eksperymentator rozpoczynał czytanie instrukcji. Instrukcje dotyczące przyjmowanej postawy ciała różniły się jedynie rodzajem przyjmowanej mimiki. Po wykonaniu zadania ponownie proszono osobę badaną o wypełnienie skali FAS.

Instrukcja dla grupy kontrolnej:

Przed toba siedzi eksperymentator, który będzie pokazywać jaka pozycję ciała należy przyjąć. Usiądź wygodnie na krześle. Rozstaw lekko nogi. Lewa nogę zegnij pod kątem 90 
stopni. Stopa niech swobodnie spoczywa na podłodze. Prawa nogę zegnij pod katem 45 stopni i oprzyj ja na palcach. Połóż dłonie na kolanach. Delikatnie unieś podbródek. Wyprostuj się. Patrz przez siebie starając się nie manipulować postawa ciała ani wyrazem twarzy. Utrzymaj tę pozycję przez 90 sekund. Poinformuję Cię, kiedy czas dobiegnie końca.

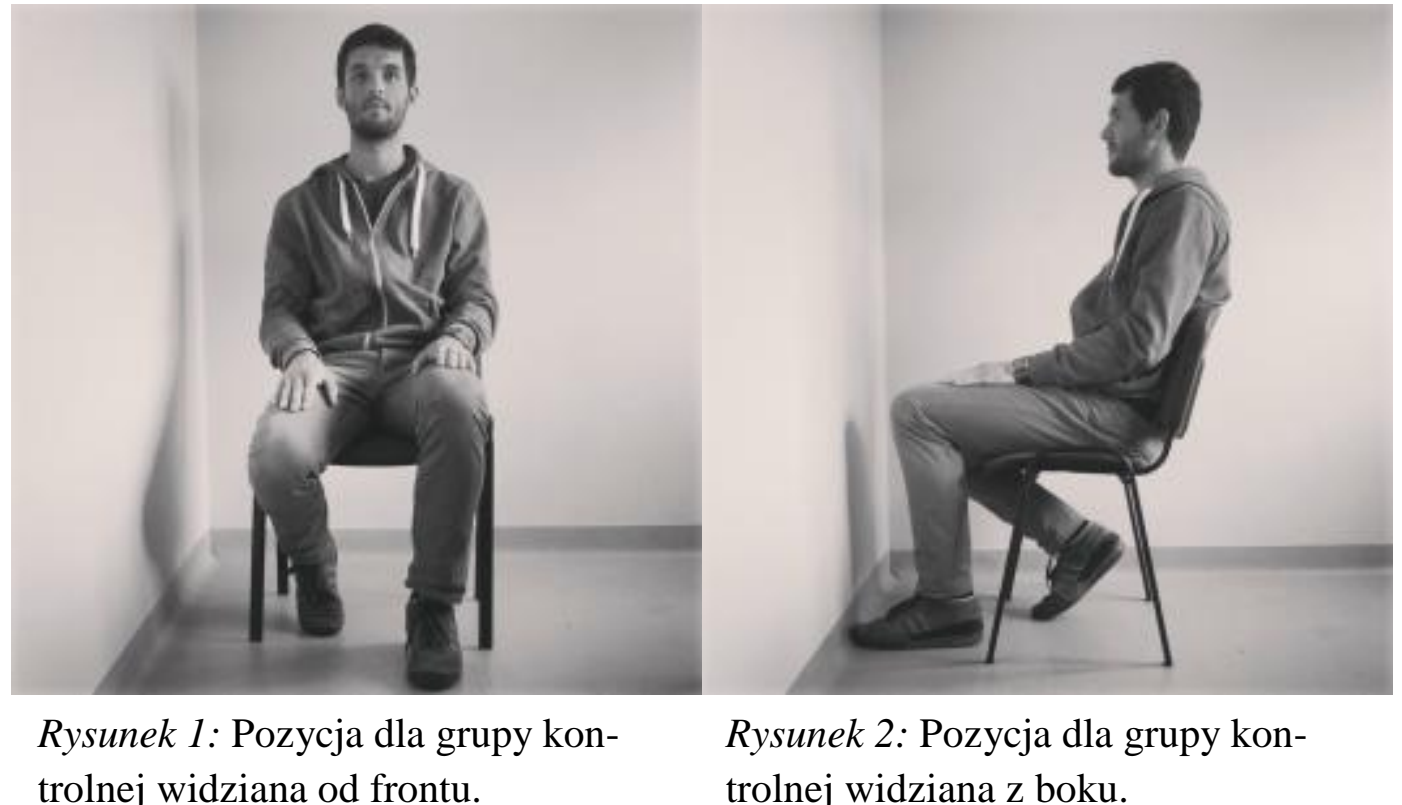
trolnej widziana od frontu. trolnej widziana $\mathrm{z}$ boku.

W pierwszej grupie eksperymentalnej, w której celem było wywołanie napięcia mięśni aktywujących się podczas uśmiechania się, przygotowane zostały patyczki jednorazowego użytku.

Instrukcja dla pierwszej grupy eksperymentalnej:

Przed toba siedzi eksperymentator, który będzie pokazywać jaka pozycję ciała należy przyjąć. Użyte $w$ badaniu patyczki sa jednorazowego użytku, jednakże $w$ celu zapewnienia maksymalnej higieny, do dezynfekcji możesz użyć wacika nasączonego spirytusem salicylowym. Usiadź wygodnie na krześle. Rozstaw lekko nogi. Lewa nogę zegnij pod kątem 90 stopni. Stopa niech swobodnie spoczywa na podtodze. Prawa noge zegnij pod katem 45 stopni $i$ oprzyj ją na palcach. Delikatnie unieś podbródek. Umieść patyczek między zębami tak, jak demonstruje to eksperymentator. Staraj się nie dotykać przedmiotu wargami. Połóż dtonie na kolanach. Wyprostuj się. Patrz przed siebie. Utrzymaj te pozycję przez 90 sekund. Poinformuję Cię, kiedy czas dobiegnie końca. 


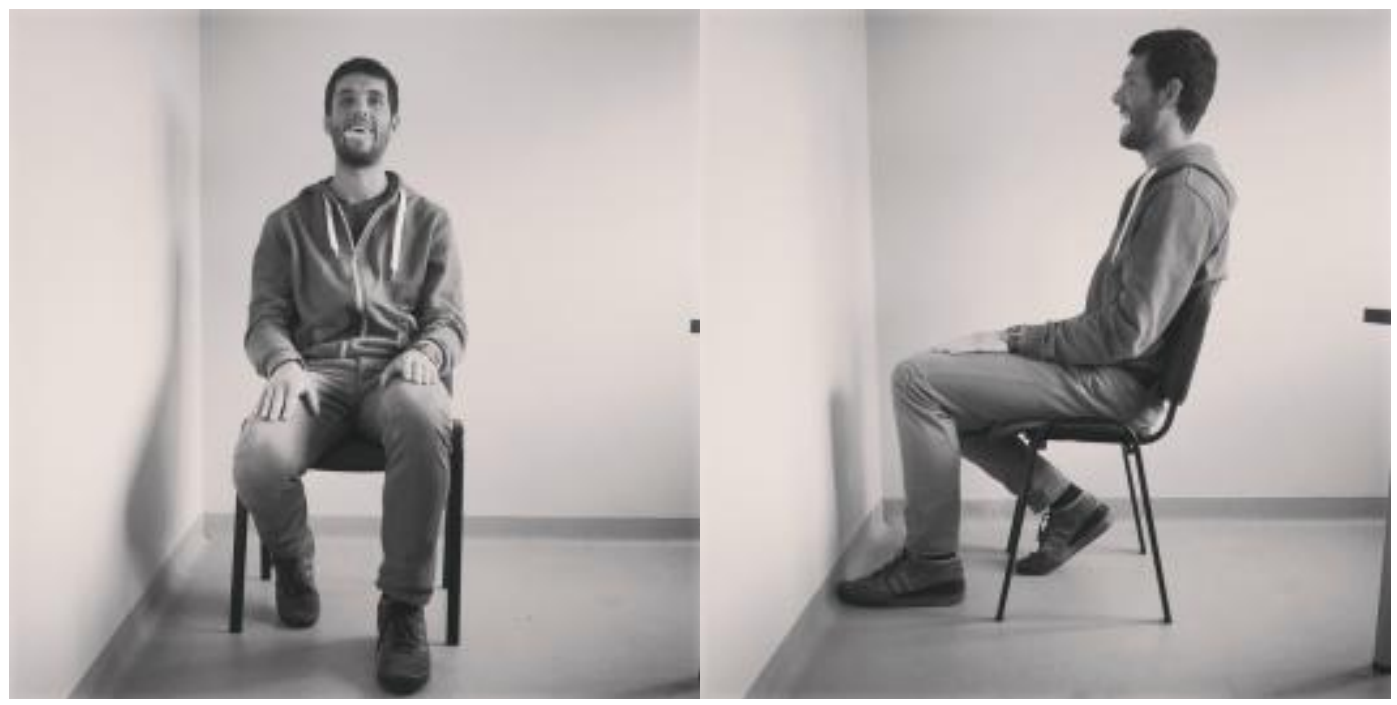

Rysunek 3: Pozycja dla pierwszej grupy Rysunek 4: Pozycja dla pierwszej grupy eksperymentalnej widziana od frontu. eksperymentalnej widziana z boku.

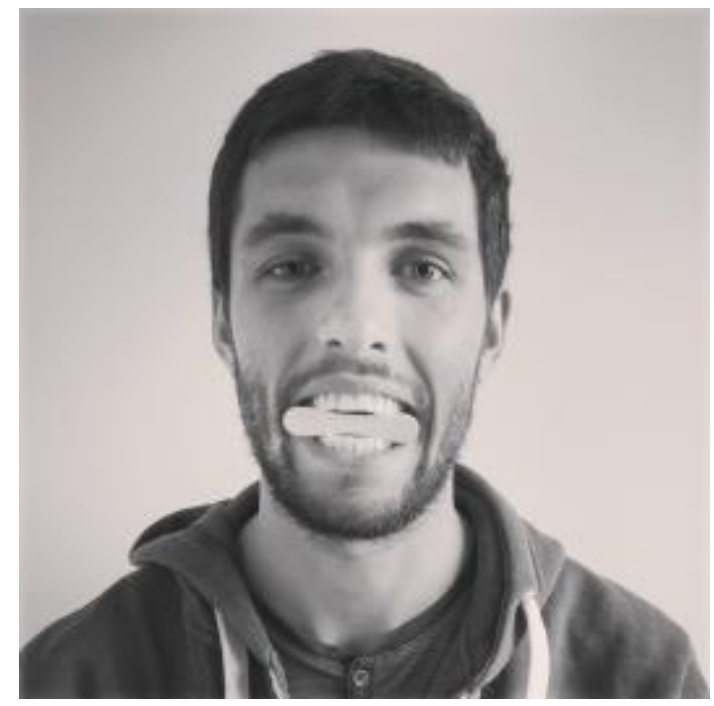

Rysunek 5: Wyraz twarzy dla pierwszej grupy eksperymentalnej.

Instrukcja dla drugiej grupy eksperymentalnej:

Przed toba siedzi eksperymentator, który będzie pokazywać jaka pozycję ciała należy przyjąć. Usiadź wygodnie na krześle. Rozstaw lekko nogi. Lewa noge zegnij pod kątem 90 stopni. Stopa niech swobodnie spoczywa na podłodze. Prawa nogę zegnij pod katem 45 stopni i oprzyj ja na palcach. Delikatnie unieś podbródek. Połóż palce na policzkach i wyobraź sobie, że sq one pokryte klejem. Wyobraź sobie, że na łokciach masz przyczepione odważniki, które ciagna je ku dołowi. Nie marszcz czoła. Wyprostuj się. Patrz przed siebie starając się mrugać wolniej niż zwykle. Utrzymaj tę pozycje przez 90 sekund. Poinformuje Cie, kiedy czas dobiegnie końca. 


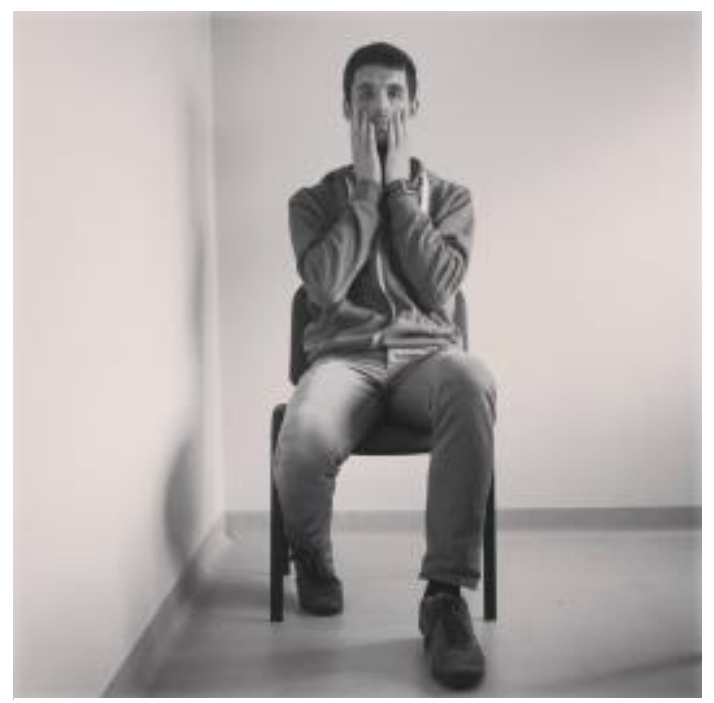

Rysunek 6: Pozycja dla drugiej grupy eksperymentalnej widziana od frontu.

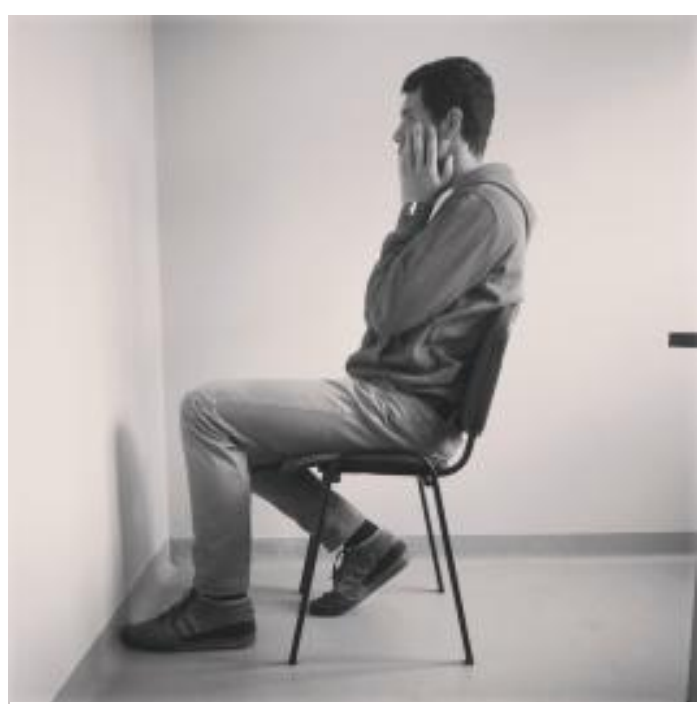

Rysunek 7: Pozycja dla drugiej grupy eksperymentalnej widziana $\mathrm{z}$ boku.

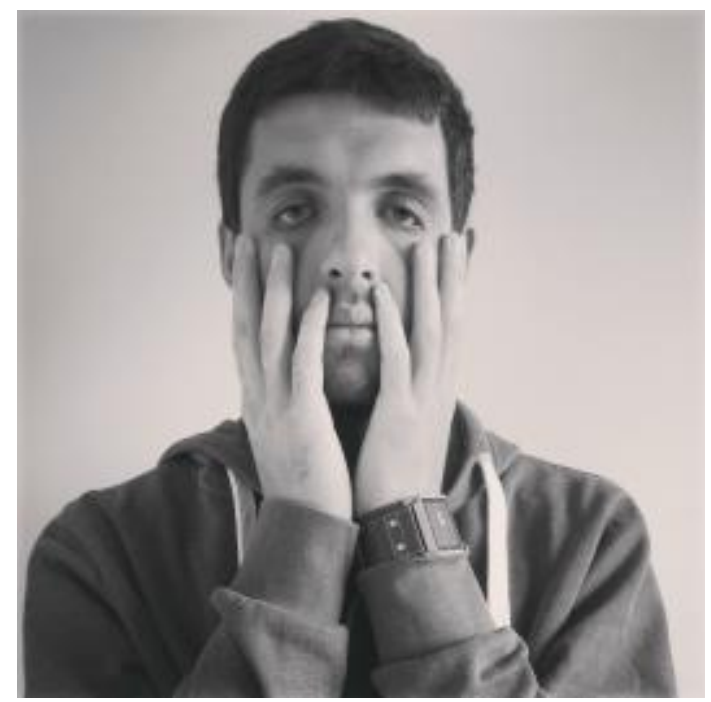

Rysunek 8: Wyraz twarzy dla drugiej grupy eksperymentalnej.

Powyższy eksperyment miał na celu wykazanie, że mimika wpływa na subiektywną percepcję zmęczenia. Podczas analizy statystycznej zastosowano test t dla prób zależnych. Dla sprawdzenia, czy grupy różnią się wynikami początkowymi, zastosowano jednoczynnikową analizę wariancji (ANOVA).

\section{Uzyskane wyniki}

W eksperymencie przebadano 75 osób, charakterystyka grupy przedstawiona jest w tabeli 1. Test Kołmogorowa-Smirnowa wskazał na zgodność wyników z rozkładem nor- 
malnym (wyniki testu K-S dla FAS przed zadaniem eksperymentalnym: 0,678, p=0,748, po zadaniu: 1,013, $\mathrm{p}=0,257)$.

Tabela 1. Płeć, wiek i liczba uczestników badania.

$\mathrm{n}$

Wiek Minimalny

Wiek Maksymalny

Średnia wieku

\begin{tabular}{ccc} 
Kobiety & Mężczyźni & Ogółem \\
\hline 48 & 27 & 75 \\
20 & 19 & 19 \\
26 & 26 & 26 \\
22,02 & 22,11 & 22,05
\end{tabular}

Źródło: Opracowane na podstawie wyników badań własnych.

Na wynikach uzyskanych od grupy kontrolnej liczącej 15 osób przeprowadzono analizę statystyczną testem t. Otrzymana istotność statystyczna $(\mathrm{p}=0,913)$ nie daje podstaw do odrzucenia hipotezy zerowej. Średni poziom zmęczenia przed i po wykonaniu zadania kontrolnego wynosił $\mathrm{M}=-0,0667$, natomiast $\mathrm{SD}=2,314$. Wynik testu $\mathrm{t}$ dla grupy kontrolnej to $\mathrm{t}=-0,112 ; \mathrm{df}=14 ; \mathrm{p}=0,913$. Średnie wyniki FAS przed zadaniem eksperymentalnym wyniosły: 28,5333 , natomiast po 28,6 , co świadczy o tym, że przyjmowanie neutralnej mimiki nie wprowadza zmian w odczuwanym zmęczeniu.

W pierwszej grupie eksperymentalnej liczącej 30 osób, w której wymuszano aktywację mięśni odpowiedzialnych za uśmiech, wyniki testu t przedstawiają się następująco: $\mathrm{t}=0,972 ; \mathrm{df}=29 ; \mathrm{p}=0,339$, dlatego nie ma podstaw do odrzucenia hipotezy zerowej. Średni poziom zmęczenia przed i po wykonaniu zadania eksperymentalnego wynosił $\mathrm{M}=0,600$, zaś $\mathrm{SD}=3,379$. Średnie wyniki FAS przed zadaniem eksperymentalnym wyniosły: 27,9 natomiast po 27,3 , co pokazuje, że pomimo braku istotności pojawiły się niewielkie różnice w średnich wynikach. Poziom odczuwanego zmęczenia został nieznacznie zredukowany.

W drugiej grupie eksperymentalnej liczącej 30 osób, w której wymuszony był zmęczony wyraz twarzy, wyniki testu t przedstawiają się następująco: $\mathrm{t}=-0,877 ; \mathrm{df}=29 ; \mathrm{p}=0,388$, stąd nie ma podstaw do odrzucenia hipotezy zerowej. Średni poziom zmęczenia przed i po wykonaniu zadania eksperymentalnego wynosił $\mathrm{M}=-0,767$, natomiast $\mathrm{SD}=4,790$. Średnie wyniki FAS przed zadaniem eksperymentalnym wyniosły: 26,8333, natomiast po zadaniu: 27,6. Pokazuje to, że pomimo braku istotności, poziom odczuwanego zmęczenia nieznacznie się podniósł. 
Dodatkowo sprawdzono, czy przynależność do grupy nie różnicowała poziomu zmęczenia (co mogło przyczynić się do braku istotnych różnic po zastosowaniu zadania eksperymentalnego). Wyniki jednoczynnikowej analizy wariancji, pokazały, że różnice między grupami nie są istotne statystycznie $(\mathrm{p}=0,818)$. Wyniki: $\mathrm{F}=0,201 ; \mathrm{df}=2 ; \mathrm{p}=0,818$ nie dają podstaw do odrzucenia hipotezy zerowej.

\section{Dyskusja}

Strack i współpracownicy (1988) w swoim badaniu wykazali, że aktywacja mięśni odpowiedzialnych za uśmiech wpływa na bardziej pozytywne ocenianie obrazków, co potwierdziło hipotezę mimicznego sprzężenia zwrotnego. Hipoteza ta $\mathrm{w}$ odniesieniu do zmęczenia nie potwierdziła się. Uzyskane wyniki nie wykazały istotnych różnic pomiędzy grupami. Warto jednak zwrócić uwagę na różnice między średnimi w obu grupach eksperymentalnych. Przy większej liczbie osób badanych, różnice mogłyby okazać się na tyle duże, że byłyby istotne statystycznie. Zaleca się zatem kontynuowanie badań na większej próbie, co mogłoby spowodować potwierdzenie hipotezy, a w konsekwencji pozwolić na wykorzystanie metody wymuszania określonej mimiki w leczeniu zmęczenia. Wydaje się, że problemem stanowiła również zastosowana skala FAS, ponieważ służy do pomiaru zmęczenia chronicznego, które przyjmuje dość stały poziom w dłuższym czasie. Co ciekawe, szczegółowe analizy wskazują, że stabilność wyników testu zmniejsza się w drugiej grupie eksperymentalnej (przyjmującej zmęczony wyraz twarzy). Korelacja wynosi $0,87(\mathrm{p}=0,01)$. Możliwe, że bardziej czułe narzędzia na drobne zmiany w poziomie odczuwanego zmęczenia byłyby bardziej adekwatne do zastosowania $\mathrm{w}$ tym badaniu. Warto byłoby również pomyśleć o skonstruowaniu nowego narzędzia w celu badania zmęczenia, złożonego z większej liczby pytań, skonstruowanych w taki sposób, aby w mniejszym stopniu zwracać uwagę osób badanych na tematykę zmęczenia. Użyte w badaniu narzędzie składało się jedynie z 10 pytań, co stwarzało możliwość zapamiętania udzielonych odpowiedzi. Ponadto, zastosowana skala służy do pomiaru zmęczenia chronicznego, a eksperyment bada ocenę subiektywnego poczucia zmęczenia w danej chwili. 


\section{Literatura cytowana:}

Buck, R. (1980). Nonverbal Behavior and the Theory of Emotion: The Facial Feedback Hypothesis. Journal of Personality and Social Psychology, 38(5), 811 - 824.

Davis, J., Senghas, A., Ochsner, K. (2009). How does facial feedback modulate emotional experience?. Journal of Research in Personality, 43, 822 - 829.

Michielsen, H., Vries, J., Heck, G. (2004).Examination of the Dimensionality of Fatigue: The Construction of the Fatigue Assessment Scale. European Journal of Psychological Assessment, 20, $39-48$.

Strack, F., Martin, L., Stepper, S. (1988). Inhibiting and Facilitating Conditions of the Human Smile: A Nonobtrusive Test of the Facial Feedback Hypothesis. Journal of Personality and Social Psychology, 54(5), $768-777$.

Szymczak, I. (1979). Mimika. W: I. Szymczak (red.) Słownik języka polskiego (t. II, 178). Warszawa: Państwowe Wydawnictwo Naukowe.

Urbańska, J. (2010). Zmęczenie życiem codziennym. Środowiskowe i zdrowotne uwarunkowania oraz możliwości redukcji w sanatorium. Poznań: Wydawnictwo Naukowe Wydziału Nauk Społecznych UAM. 